\title{
The clinic-biological progress of patients on ARV under D.O.T
} O Lyli*, V Bithe, A Nanga, V Sembong, I Krauss Sr, I Saar Sr, Fr Faisandier, ARC Solofo et ses and C Bayiha

\author{
Address: Bertoua, Cameroon
}

* Corresponding author

from Frontiers of Retrovirology: Complex retroviruses, retroelements and their hosts

Montpellier, France. 2I-23 September 2009

Published: 24 September 2009

Retrovirology 2009, 6(Suppl 2):P69 doi:10.1186/1742-4690-6-S2-P69

This abstract is available from: http://www.retrovirology.com/content/6/S2/P69

(C) 2009 Lyli et al; licensee BioMed Central Ltd.

\section{Context and justification}

- Cameroon is a Central African country of limited resources with about $16 \mathrm{M}$ inhabitants in 10 administrative regions

- Surface area: $475000 \mathrm{~km}^{2}$

- Prevalence: 5,5\% EDSIII 2004

- PNLS .... Decentralisation (CTA, CTAFF, UPEC)

- Representing about $1 / 4$ of the total surface area of Cameroon, the East Region is under populated, with a total population of about $945000 \mathrm{~h}$. This gives a population density of about 3 per $\mathrm{km}^{2}$. It has one CTA and 8 UPECS of which only 5 are functional. At $8,6 \%$ it has the second highest national prevalence rate of HIV in the Country.

- There are 14 landlocked health districts having as a distance unit, $100 \mathrm{~km}$ to undertake in about 4 to 6 hours depending on the season, which leads to the most recurrent reason given by patients to justify their poor observance of treatment.

- Resolution: D.O.T initiative

\section{Objectives}

- Ameliorate the observance of patients on ARV who live far from the care units and whom distance leads to poor appointment observance and follow up of ARV and O.I.D

\section{Methods}

A - Role of sites

- Massive sensibilisation and screening for the recruitment of HIV+ patients

- Choosing patients belonging to associations

- Collection of samples to be analyzed at the appropriate CTA

- Transportation of patients eligible for ARVT to the CTA for evaluation and inclusion in the study

- Weekly sharing of ARV and O.I.D

B - Role of the tutor CTA

- Receiving and analyzing samples for PTW

- Clinical evaluation of patients for eligibility and treatment of ARV according to the national directives.

- Making available Hospital Unit of ARV and MIO

- Clinical and biological follow up every 6 months

- Collection and analysis of data

- Networking the CTA and these Hospital Unit for eventual problems 


\section{Results}

- All the peripheral patients on D.O.T did their two biannual workups expected during the period of study.

- No patient on D.O.T missed his appointment for supplies of ARV or drugs for prophylaxis of O.I

- No patient on D.O.T on ARVT had an O.I during the period of the study

- Total weight gain of patient on D.O.T was between 5 to $15 \mathrm{~kg}$.

\section{Conclusion}

- The global management of PLHIV is a team and harmonious problem

- A permanent and active coaching can ameliorate the success of ARVT for the PLHIV by reducing the multiple difficulties they face, be they linked to:

- The patient himself and his surroundings

- The drugs,

- To the health personnel

\section{Thanks}

- The team of the tutor CTA involved in the study;

- Mme Bithé Veronica, Mme Sembong Valérie, Mme Nanga Aicha

- The Catholic Health Center team of Doume, more especially sister Isabella Krauss and Fr Faiseandier

- The Garoua-Boulai team (Dr Solofo and his community agents)

- The Doume DH team ( Dr Bayiha and his collaborators)

- The Doumbi Catholic Center team, especially Sister Louise SAAR.
Publish with Biomed Central and every scientist can read your work free of charge

"BioMed Central will be the most significant development for disseminating the results of biomedical research in our lifetime. " Sir Paul Nurse, Cancer Research UK

Your research papers will be:

- available free of charge to the entire biomedical community

- peer reviewed and published immediately upon acceptance

- cited in PubMed and archived on PubMed Central

- yours - you keep the copyright

Submit your manuscript here:

http://www.biomedcentral.com/info/publishing_adv.asp 